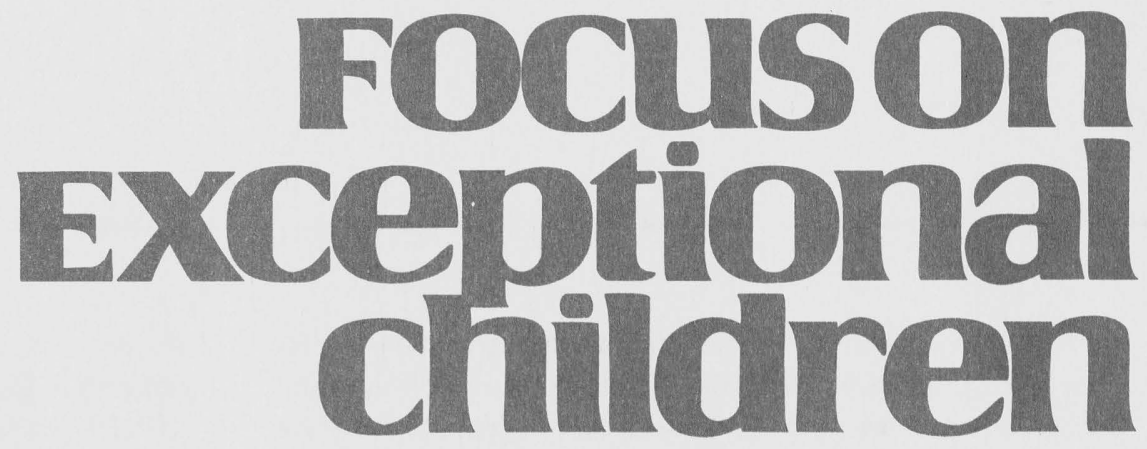

\title{
The Missing Link: Students Discuss School Discipline
}

\author{
Sue Thorson
}

All too often students are studied, tested, and acted upon without acknowledgment of their own experiences and ideas. Procedural decisions are based upon the conceptual frameworks of adults who may have had very different school experiences from those of the students they are analyzing. This causes misperceptions and misunderstandings, misplacement, and sometimes even mistreatment. Therefore, asking the students themselves about a common experience may be valuable.

To this end, I began a discussion with students about their experiences in a Saturday detention. The conversation expanded to include the school's discipline and then to the school as a part of the community. The experiences the students related ranged from amusing to disturbing. Their provocative insights will be useful to educational planners.

Besides the information it produced, this form of research seemed to have intrinsic value. The students reported that they enjoyed the opportunity for individual discussions on serious topics. Even the most playful individuals took the time and made an effort to seriously consider the topics we discussed. They read their transcripts, even when reading was difficult for them. They reported having complementary discussions of our conversations with family and friends.

\section{THE PROJECT}

Student placement often was precipitated by behavior problems in general classes, so discipline was a major concern in my high school resource room. Long before they reached high school, my students had learned how to beat the system, drive teachers crazy, and tune out of any experience that remotely resembled academic learning. Of course, good pedagogy increased attention, and behavioral techniques decreased behavior problems, but neither immediately resulted in acceptable behavior outside our room. Detentions and suspensions were assigned frequently, but they seemed to have little effect on these students.

When I served my triennial duty as detention supervisor, or I discussed school life with my colleagues in general education, I found that they had the same experiences with some of their students. More specifically, good lessons were useless when a student wouldn't pay attention; relationships were difficult to build in large, brief class sessions; and behaviorism was tricky to integrate into the secondary school environment. The result was that students were sent to the office and given either a detention or a suspension.

Sue Thorson is an assistant professor of special education at the University of Maine, Farmington. She formerly taught in a resource room for students with mild cognitive disabilities. 
Although replete with theories about and suggestions for effective discipline, research did not provide any new information. Effective discipline has been an educational issue for Mediterranean-European cultures since ancient Egyptian times (Butts, 1947). Jewish traditions also provided a foundation for our educational practices. Hebrew teachers were encouraged to punish wrongdoing (Barclay, 1959); the Hebrew word musar, which means education, discipline, and chastisement, appears in the book of Proverbs (circa 900 B.C.E.) 30 times (Brubaker, 1947). Discipline, including punishment, has been an integral part of American education since colonial times and still is espoused by many parents, administrators, and teachers. Keeping students in school after dismissing the others is a punishment long accepted in our schools.

Many researchers maintain that punishment is ineffective, community members question its morality, and judges increasingly rule against it. Some researchers blame society, and more specifically the parents, for children's misbehavior. Others say that adolescence is a stage characterized by rebellious, antisocial behavior. Alternative theories suggest that the school, the teaching, or the curricula should be changed to eliminate discipline problems.

\section{Focuson
Exceptional children}

ISSN 0015-511X

FOCUS ON EXCEPTIONAL CHILDREN (USPS 203-360) is published monthly except June, July, and August as a service to teachers, special educators, curriculum specialists, administrators, and those concerned with the special education of exceptional children. This publication is annotated and indexed by the ERIC Clearinghouse on Handicapped and Gifted Children for publication in the monthly Current Index to Journals in Education (CIJE) and the quarterly index, Exceptional Children Education Resources (ECER). The full text of Focus on Exceptional Children is also available in the electronic versions of the Education Index. It is also available in microfilm from Xerox University Microfilms, Ann Arbor, MI. Subscription rates: Individual, $\$ 30$ per year; institutions, \$40 per year. Copyright (C) 1996, Love Publishing Company. All rights reserved. Reproduction in whole or part without written permission is prohibited. Printed in the United States of America. Periodicals postage is paid at Denver, Colorado. POSTMASTER: Send address changes to:

Love Publishing Company

Executive and Editorial Office P.O. Box 22353

Denver, Colorado 80222

Telephone (303) 757-2579

Edward L. Meyen

University of Kansas

Richard J. Whelan

University of Kansas Medical Center
Even though all of this information was interesting, it didn't answer my question about how to maintain discipline in my resource room and in general programs. I don't like to punish, but it does seem to have the desired effect at times (Millman, Schaefer, \& Cohen, 1980; Weber, 1984), although in other instances misbehavior actually increases (Gretzinger, 1988; Kreisberg, 1990). I, too, wonder at the state of society and the way some parents do or do not rear their children, but I can do very little about it. And, though adolescents do seem to go through stages, high school teachers do not have the luxury of waiting for them to reach adulthood.

The only hope seemed to be a change of pedagogy, but how? Expand the curriculum or go back to basics? Get stricter or become more student-centered? Technology or relationships? The choices are infinite, the answers are contradictory, and I have a student climbing up the air shaft now.

After getting him down, I asked Harry (not his real name) why he did that and he explained that, like Mount Everest, it was there. Knowing that it would contribute to my growing discomfort was an added bonus, although Harry did not have malicious intent. So off he went to the office while I retrieved my temper. Although I yelled at him often and sent him to the office at least once a week, Harry later confided that my caring and high expectations had stopped him from making a suicide attempt on more than one occasion. This and similar studentteacher interactions led me to believe that the students and I had very different understandings of the world and the discipline process. Kreutter's (1983) research suggests that students and teachers do indeed perceive discipline differently.

After a move to university teaching, I had the opportunity to further my inquiries with students and the time to organize

\section{STATEMENT OF OWNERSHIP, MANAGEMENT AND CIRCULATION}

Date of Filing: October 1, 1996

Title of Publication: Focus on Exceptional Children

Frequency of Issue: Monthly (except June, July \& August)

Location of Known Office of Publication : P.O. Box 22353, Denver, Colorado 80222-4306

Location of Headquarters of Publisher: P.O. Box 22353, Denver, Colorado 80222-4306

Name and Address of Publisher, Editor, and Managing Editor: Stanley F. Love, P.O. Box 22353, Denver, Colorado 80222-4306

Owner: Love Publishing Company

Extent and Nature of Circulation:

Total No. Copies Printed

Average No. Copies Each Issue During Preceding 12 Months 2495

Paid Circulation

Sales through Dealers, etc. Mail Subscriptions

Total Paid Circulation

Free Distribution

Total Distribution

Office Use and Left Over

Total

$\begin{array}{rr}0 & 0 \\ 1965 & 1997 \\ 1965 & 1997 \\ 441 & 301 \\ 2406 & 2298 \\ 89 & 122 \\ 2495 & 2420\end{array}$

I certify that the statements made by me above are correct and complete.

Stanley F. Love Publisher
Kristin Kennedy Editorial Assistant 
and reflect upon their responses. The results indicated that my question was all wrong. Although they don't like it, most secondary students I talked to saw a need for discipline. They saw its administration, however, as symptomatic of the problems of the school community as a whole.

\section{THE PROCESS}

Qualitative researchers study people's understandings of their worlds (Bogden \& Biklin, 1992). Ethnography is a specific method used to investigate the complex meaning systems of behavioral organization, self-concept, and societal structure (Spradley, 1979). Husserl (in Barritt, Beekman, Bleeker, \& Mulderij, 1985) describes phenomenology as an attempt to understand the constitution of the conscious mind, which is the basis of all knowledge. To understand life, we must turn to experience, forgetting our preconceived ideas and looking at occurrences with fresh eyes. (Barritt et al.)

The attempt to look at an experience through another's eyes enables the researcher to begin to achieve an awareness of different ways of thinking and acting, to identify new possibilities. Barritt et al. (1985) suggest that these might best be discovered by attending to variations in behavior rather than the norm. Thus, the initial attempt to understand the student's point of view was made using an ethnographic method of research based on the philosophy of phenomenology. Detention results from many types of students' deviation from the behavioral norm, so students in detention were good candidates to interview.

To understand a student's constructions of meaning, the inquirer must be aware of many factors, including the individual's life outside of school, nonacademic strengths, and the perception of obstacles (Gay \& Williams, 1993). Therefore, although each student was asked to respond to core issues and participate in the same series of conversations, deviations from the topic of detention also were pursued, to discover other issues that might affect the student's perceptions of discipline. To respond to student direction, a conversational rather than an interview technique was constructed. Although the conversations were only loosely directed by common social reactions, they were similar in general content, indicating that the students had similar concerns.

I was able to meet with students assigned to Saturday School detention in a large Southern California high school. The reasons they were assigned to detention were similar to those identified nationally: tardiness, truancy, and disrespect (Dinkins, 1981; Duncan, 1991). Fourteen students, seven from general education and seven from special education, volunteered to talk with me. The students included ninth through twelfth graders and one graduate of the special education program. Both young men and young women participated. Although all had lived in the United States for all or most of their lives, they were of African, African American, Asian, Latino, Mexican, and European American heritages.

After hearing an explanation of the study, the students chose a pseudonym and we began the individual conversations. The earliest discussions revolved around my concern with discipline. I asked all the students individually why they received the detention, why their friends received detentions, and how they would deal with these misbehaviors if they were the principal. After reading the transcription of our first meeting, the student scheduled a second discussion during lunch or after school. At that time I asked about the roles of tea ners, administrators, friends, and family in their education and in their decisions about behavior. I tried to elicit a continuum of misdemeanors and consequences, but each student moved to explore issues of communication and community instead.

The third visit aimed to clarify the previous transcription and to develop a description of the school and the participants. Finally, we had lunchtime pizza parties for all of the participants, at which time they were given a copy of the summary of their conversations and discussed how they felt about the process. They also were invited to contact me if they wanted to change their part of the summary, and they all received a letter of recommendation describing their role in the research.

The conversations were strikingly similar across placement, age, gender, and ethnic lines. The students' comments about rule orientation, strictness, and student responsibility reflected the same continuum from conservative to liberal that we see in society at large, but their desire to please their parents and their concerns about communication and relationships within the school community were unanimous.

\section{THE RESEARCH IS RIGHT}

As the discussions progressed, the research I had reviewed was verified. Although the students contradicted each other and themselves, they clearly supported all of the theories. Appropriate discipline, it seems, depends upon the situation and the individual.

The students agreed that, in general, rules are necessary and that rules should be followed. They were assigned detention because they did not understand the rules, or the teacher was unfair, or the specific rule was not appropriate.

Chaquan, a general education freshman, complained, "They've got rules for everything you do." She explained that she got in trouble because she didn't always know the rules on a new campus, "because on the first one [misdemeanor], you're dazed ... the first one you're supposed to tell them, or talk to them, [but] they're ready to give you a referral or detention, right away."

Johnny, a ninth-grade special education student with bilingual skills, was disciplined often because he misunderstood 
directions or did not understand rules. Once his PE teacher gave him detention for not following instructions. "Well," claims Johnny, "I did follow [the directions]. He told us, "Go around.' Well, around where? And like, that's it. That's how I got in trouble." Sometimes, the teachers misunderstood him. For example:

... she said I cussed her out, but I didn't cuss her out. I was cussing this kid out. And she thinks I cussed her out, but I didn't. I didn't say her name. I just said this kid's name. So I got in trouble, I got suspended for two days.

Nivek, a tenth grade special education student, compounded his problems when he lost his temper because the proctors misunderstood him:

I got it [detention] because I was just walking around the school and everything like that ... cuz I went to the restroom. And the proctors didn't believe me, that I had a pass ... and they sent me to $\mathrm{ABC}$ [the school discipline room]. . . . So I got mad about it ... and they told me, "You better calm down." I said, "No. It's not fair just bringing me over here, just cuz I went to the restroom." ... so they gave me Saturday detention because I wasn't supposed to be mad. This is a weird school, man.

Tom, a general education sophomore, has received only one detention this year. It was because he returned to school late after an appointment. After he was assigned the detention, his mother attempted to provide an excuse for him, but after several unsuccessful contacts with the school, she asked him to go ahead and serve the detention.

Rebecca, a general education junior, and her friends were assigned detention because they frequently were late to class. She explained that they were meeting at a far corner of the campus during the mid-morning break and couldn't hear the late bell. After the detention they changed their meeting place.

Several students had been assigned detention for leaving campus during the lunch hour, a privilege reserved for seniors. All of the students believed this rule was unfair. Some stayed on campus after getting caught; others maintained that the food was not good and the rule was unjust, so they were resolved to go out to lunch. Antashia's mother requested an off-campus pass so her daughter could eat lunch elsewhere, but it was denied because she was not a senior. Antashia said:

Forget it. I'm gonna eat either way it goes. That's me. I like to eat. I could eat some food, and I'm not gonna stop eating for nobody. You can punish me, they can have me in Saturday School every Saturday, but if I'm hungry, I'm gonna leave and go get some food.

Students who spoke of leaving campus habitually for lunch were careful to add that it was important to return to campus in plenty of time to get to class promptly, because they didn't want to miss learning opportunities.
Other students worried about the conflict of school rules with their personal priorities. Rebecca eventually failed her first-period class because she could not get her little brother to child care and then get to school on time. Both special and general education students disagreed with the school rules against fighting. They agreed that fighting on campus was not desirable but explained that in some situations they had to defend their honor or physical well-being. Casper, a special education sophomore, tells of being maneuvered into fighting in the office:

I got in a fight with this kid in the office, in front of the security guard. I didn't plan it that way. I was in my class and the kid, when he told on me, cuz he was messing with me and he said that, he told on me that $I$ was always messing with him. And so I went in the office and he was in the principal's office and I was sitting down, and he all, like mumbling some stuff and he asked the lady, "Can I go get a drink? Can I go get a drink by the drinking fountain?" The lady said, "Yeah." He walked by me, he started to, he like said something. I ignored him, then he came back in and he got in my face and so I stood up and he started talking and then he pushed me ... so I pushed him and he tried swinging and he hit me in the side of the head. And then I hit him in his face and the security guard jumped over and I almost hit the security guard.

... the kid pushed me, then he swung at me. Then I

hit him ... Cuz then everybody in the school would be like, "You didn't swing back," . . . even my mom said, "After the first swing, don't stand there."

Tracy, a general education sophomore, was one of the students who agreed with Casper: "Sometimes you got to fight. . Sometimes you can't help it. Somebody go up to you; they swing at you, what you gonna do then? Stand there and say, 'I won't fight,' and get beat up?"

A few students believed detention was a deterrent to their own future misbehavior, although they did not think it was effective for others. They generally said they would avoid detention in the future because it was a waste of time.

Stephanie, an 18-year-old special education sophomore, said, "It stopped me. . . I learned from it that I shouldn't go back in that place again." She added, ". . . it was too boring for me. I couldn't stand it. When I get bored, I just want to walk out."

Alissa and Angela, both in general education, agreed that they did not want to repeat the experience because they had better things to do with their time. Larson and Karpas (1967) seem to be correct when they refer to detention as a procedure designed to "annoy the annoyer."

Don, a special education junior, saw detention as an opportunity to reflect:

Just to get away from the students, and you know, keep you by yourself in a quiet place. . . it helped me a lot. Cuz I'd be like, “Man, I gotta do better so I won't go back in here no more. I miss all my friends." ... 
[It's] kinda like a little jail. Not a bad one. It's just a place to keep you until you think you have learned your lesson, not to get in trouble, not to be bad, talk back to the teachers or anything.

Johnny, too, says a detention experience is punishing to him and makes him want to behave better. Unfortunately, both young men have trouble following through with their good intentions and are assigned detentions frequently.

Most of the students did not see detention as a real deterrent. Chaquan said, "I' $m$ going to be here for the next three weeks. So if it would have had an effect, then nobody would be here the second time." Angela, the general education sophomore mentioned earlier, does not see punishment as a change agent. She explains:

All of the punishments that we've had, none of the kids respond to, I mean, not one of them do. And if they really wanted to stop, they'd stop on their own. This wouldn't make them stop.

Antashia, the general education junior, agrees:

OK, I left to go get something to eat, OK, punish me... I mean, Saturday School, to me, and probably to basically everybody else, was just like, "Oh, I'm not gonna go to class. I can just go and get that little detention over with in Saturday School." . . . It's no big deal. . . It wouldn't stop me from doing the things that I do....

Like many researchers (e.g., Block, 1987; Brown \& Payne, 1988; Feldhusen, 1978), the students identified parents as important contributors to school discipline problems, but only in the case of other families, not their own. They were pessimistic about the futures of friends without parental support.

Carla, a special education sophomore, talked about her friend Mike, who dropped out:

It's cuz like, I don't know, it seems like it's the way the parents are with you when you're little. They got raised with gangs, their parents were in gangs and drugs and all that. And they were never respectable to people. . . And at school, you know, they don't care. They'll talk back to whoever they want, whenever they want.

... Some people just drop out, and they never do nothing for their life. They think it's so easy, just dropping out. And they say, well, you know, "I'll have money later; watch, I'll get a job." And they can't and you know, they sell drugs and things like that and stuff.

\section{Antashia disagreed:}

I've been knowing some of them since the fourth grade and up. .. It's like, they have those parents that don't care. ... .

You can't blame nobody but yourself. I can't simply say it's my mom's fault that I'm here [in Saturday School]. She didn't have anything to do with it. She's not the one I got in the car with. . . She raised me, and she's not done raising me. But when I'm at school and she's at work, I know what I have to do, and I just chose to do the wrong thing that day. I can't blame her for it.

Instead of blaming her mother, Antashia emphasizes the positive effect her mother has had on her school experience. Her mother helped her with homework, taught her to respect her teachers, and continues to encourage her when school becomes too frustrating.

Schoolwork was both cited and implied as a reason for misbehavior. Kratzert and Kratzert (1991) claim that changes in methodology would reduce frustration and thus improve discipline. Some students complained about boring classes and uncaring teachers. Others had no compunctions about missing classes to go to a party, visit friends, or just "hang out."

The students agreed that it is the teacher's job to maintain control. Good teachers, who teach interesting materials clearly, rarely have discipline problems. Don says, "If they're so good with kids, they shouldn't have no problems with their detention and giving them $\mathrm{ABC}$."

Rebecca tells of an algebra teacher who does not do so well:

... my teacher was doing this problem, and she just started talking about it, how to do it, and all of a sudden she started going somewhere else, explaining something else. . I got lost. So I started falling asleep, and I fell asleep. She was talking too much. Then by the time I woke up, I guess it was five minutes later, or ten, she was still talking about the same problem ... nobody did the homework last night. Everybody came today with the same question, "How do you do it?" Cuz nobody understood it, and then she tried to explain it again today.

Her history teacher keeps Rebecca interested by discussing campus events and current issues along with the standard history curriculum.

Chaquan, does her work for biology, but not Spanish, because:
My biology teacher, she's good. She teaches us, she ex- plains it, when she goes to the notes, she'll tell us how to do those, she shows movies and all that; I mean movies [about] insects and reptiles and all that. ... But my other teachers, I don't understand what they're say- ing. Like my Spanish teacher, I didn't even know what she was talking about. She would give us, like, nine as- signments to do in one week. And then didn't explain how to do most of them. And she wanted to know why [we got] low grades in the class.

When students decided to improve their behavior, the reason was to get credits for graduation, grades, or employment. Don summarized, "So I thought about it to myself, and I'm gonna behave myself. If I could ace those classes, get out of school, go where I've gotta go, do what I've gotta do. No problem."

Students who are unhappy with the quality of their education may exhibit maladaptive behaviors as a form of resis- 
tance (Kampol, 1994; Shor, 1992; Willis, 1981). Special education students were especially resentful of the poor quality of education they were receiving, and they talked about misbehaving in response.

Carla, who is disciplined frequently in school, explains:

Like, since I started going to high school, I was like, “. . . I'm gonna drop out. . . What's the big thing about dropping out? I don't have to go to school; I don't have to do homework; I don't have to do nothing." And when I went to ninth grade, there was just nothing. . . . I had to wake up early and go to school and not do nothing. I didn't have to even carry books, or pencils, or paper, nothing. I never did carry nothing. And I don't know if it's just only the Special Ed, or other people, cuz I used to see, like some of my friends they would carry books, they would carry, you know, like, a folder and two books. And me, it was like, I never carried nothing. Like, you know, I don't know, I felt like I'm not going to learn nothing when I get out of high school.

Casper also is in trouble constantly with the school and municipal authorities. He describes a teacher who:

\begin{abstract}
... wouldn't give no one homework, cuz like no one ever did it. And I was like, "Can I have homework?" He's all, "No, I don't want to give out homework." I was like, "Well, can I take the math book home, for I can do some math." "No, I can't give out the math books. You won't bring it back." And so I never really had work. ... And if I don't get homework and everything, how am I supposed to learn and stuff?
\end{abstract}

Casper goes on to explain that, although he enjoys playing Monopoly and watching popular movies, he wonders how these activities contribute to his learning. He also gleefully describes the many ways he and his friends devised to get even with teachers who were rude to them or who talked to their friends instead of teaching the class:

Sometimes, when the teacher would be on the phone, we knew she'd be on there for a while, so we'd start talking, "What are we doing tomorrow; what are we doing now," and talk around and making jokes and stuff. . . Then, like we'd get loud and stuff. And she'd like, "I'm on the phone!" And some kid would come out with a smart remark and stuff. And she'd like, "Who said that?!" And she'd turn her back so she didn't know who it was, and we're, "We don't know." And one time, some kid threw a bottle of glitter and it hit her... and it hit the board. She was all, "Well, who was that?"

It's like, if we're just sitting there, we can't, if we're sitting there and everything, and she's on the phone, we're not learning anyway, so we start. ...

Tracy, a sophomore in the general education program, has a teacher who singles her out for discipline. She explains:

You can't just talk to yourself, unless I'm going crazy. . . . So I don't see how he can just single out one person and just give them detention, and not give the other person detention that they was talking to, or that was talking to them.

\section{The problem is compounded because:}

I figure if I'm going to get in trouble, I'm gonna annoy him as much as I can. I'm already going to get in trouble, he deserve it, if he gonna keep singling me out, so I get on his nerves! ... If you know you're already getting in trouble, why shut up?

Not surprisingly, students often cited friends as a reason for getting in trouble. Truancy, especially, was a group activity. Students skipped or left school to be with their friends, attend "ditching parties," or spend private time with girlfriends or boyfriends. Students, however, also cited friends and peers as a motivation for behaving well. Alissa sees herself as a potential role model:

I hope by my attitude that I can influence people around me; if they're my age or my friends who might be acting rowdy or whatever. I hope that they can look at me and settle down a little bit. You know, just try and be a good example for every people; not necessarily to walk around and say, "Oh well, look at me. I'm doing this and that!" but, just hold myself, the way I carry myself and be a good person.

Don is another student who saw a responsibility to be a role model for his peers:

\begin{abstract}
My job as a student is to do my work, be the best I can be, make other people look at me and want to try to be like me, you know, do the things I do. Like if they see, like say you used to be a bad person, and then all of a sudden, you change yourself around, and like, you're doing good. So then, like the people that's still being bad, they'll look at you like, "Aw, you used to be bad like me. So now, I think I want to get like that, and be smart." Have a little sense, you know.

... I'm trying to follow it through ... leave a good footprint there, another person can follow.
\end{abstract}

\section{THE MISSING LINKS: FUN, PARENTS, COMMUNITY}

Although pieces of the students' beliefs can be found in the research about discipline, some factors were interpreted quite differently. For example, the students claimed that sometimes they misbehaved purely for the fun of it, without ulterior motive or concern. Although many student problems theoretically are caused by parents, these students looked to their parents for support as they pursued their educations. Most surprising to me were the sophisticated theories of educational communities evolving from their discussions of discipline.

Many expressed the belief that rules are made to be broken; rules exist as a challenge to creative minds. They enjoyed breaking rules and confessed that they would fight con- 
trol, even when they knew it was in their best interest. These students saw school as boring, getting around the rules as a sport, and detention the penalty for getting caught. They were firm in their claim that they intended no malice toward teachers when they broke rules or disrupted class.

Casper wanted to give his teachers a hard time sometimes because otherwise "there' $\mathrm{d}$ be no fun in going to school." $\mathrm{He}$ continued, "[We would], just out of fun, turn out the lights, and throw a desk over, no one ... knows who did it!"

Carla, who enjoyed her biology class because she learned things, also liked a class in which the students misbehaved regularly. She explained, ". . . and they would start throwing papers and keep on doing things, you know? And I liked that class, because we never did nothing, and I got used to it. . . . He was my best teacher!"

Robert, a graduate of the special education program, and Johnny agreed that the pleasure of truancy is in the chase rather than the day off. Johnny says, "Running away from proctors, you know, that's fun." Robert complained:

Some of the proctors let you leave. . . But, I mean, when they let you leave, that's no fun. . . . [I would rather] send somebody to go talk to a proctor, tell the proctor, "Hey, there's somebody over here, doing this." Proctor turns around, walks that way, and you walk right behind the proctor, out the gate ... to get by the proctor, or like that, it was just like a big game, pretty much.

[Once you're off campus] it gets boring. During the day, nothing. . . . You can't go out, school police sees you, you're in trouble. Now if they see and you run from them, now that's fun. You have them chasing you and they're pissed off like hell.

Casper explained that eliminating weapons on campus was difficult, partially because, although students might understand the wisdom of the policy, many could not resist the challenge of smuggling in any contraband:

They might have metal detectors at the front gate and stuff, but a kid could always have a friend go in with no weapon or nothing, then go to the back gate, when no one's around, and then hand them a gun, couple of guns or something, then the other kid is gonna go through the metal detector, how can they get busted or stuff? ... It's just more challenge for the kid to get in. And they'll be like, "Well, let's see if we can get something in today," and it's the challenge, cuz when someone says, "You can't bring this, or you're gonna get busted." Like Walkmans you can't bring; people are like, "Well, we're gonna bring them in our bag anyway, it's like ... Well, let's see if we can get past all this," or hop over the fence or something, or throw them over the fence and then go pick them up or something. It's easy, like it can be done at any school.

The students I talked to were adamant about their responsibility to control themselves. They denied that any outside agent actually could change their behavior but cited parents and other family members as primary influences in their lives. They saw family members as sources of inspiration and encouragement; above all, they wanted to please and impress their parents. The main reason for trying to behave, and even for staying in school, was concern for parents. All of the students spoke respectfully of their parents and initiated a discussion about how important it was to make them happy or at least protect them from disappointment. Because the parents were notified of the detention assignment, some students resolved not to repeat the experience.

Angela's mother was angry because her daughter left campus, but explained her anger and the reason for the on-campus rule. Angela said she won't leave campus again until she has a pass, partially because she prefers to follow the rules, partially to avoid Saturday School, "but mostly because of my mom, because I'm supposed to listen to her."

All of the students were concerned about parental reactions to their school performance. Rebecca tries to stay out of trouble because, "every time I do something like that, they lose more confidence." She and her younger brother are the only two members of the family who have not dropped out of school.

Like Rebecca, Nivek is determined to graduate, "Not for me. But for them, so they'll be proud of me."

Chaquan is not afraid of punishment, because her mother discusses behavior problems and advises Chaquan how to avoid them, but she doesn't like it when the office calls and bothers her mother about misbehavior. When Johnny's mother got upset about the number of times he was suspended, he stopped doing things that would result in suspension.

Angela concludes:

Well, I think that we should all respect each other, because, I mean, that's the way my mom teaches me. My parents are from Africa, and they teach respect. My mom has taught me to respect everybody, all my elders. ... And it's just that I think we all need respect, to respect our elders mostly. And then our peers also. I think that's the best way to get across with people. If you respect them and they respect you back. . .

The students agreed on the importance of parent involvement. They emphasized repeatedly the importance of contacting parents frequently and courteously. Because they thought parents ideally should make decisions about punishment, they were frank in admitting that they would (and do) attempt to interfere with school contacts by erasing answering machines and intercepting mail. The school is responsible, however, to continue to call, write, or even visit until contact is made. Chaquan added:

But some parents don't really care. There's a lot of kids up here, they come to school when they want to, and they leave and whatever, and their parents don't care. . . I don't think there is nothing to do. . . If they don't care, then there's nothing you [as an administrator] can do. 
Even then, Chaquan concluded, it may be that the parents just don't understand the importance of the problem, so administrators should continue to work with the family while pursuing other ways of dealing with the student.

Students who received support from their teachers noticed it and appreciated it. These students expressed concern about disrespectful behavior toward adults and wished some teachers would discourage it more firmly. Others saw the lack of communication as an important reason for ongoing behavioral problems.

Although students did not credit teachers as a primary influence in their lives, the special education students clarified that teacher support was important to their growth. Don explains:

They say, "You got the talent, you can do what you want to do. But you know, you gotta ace this class too, along with what you want to do. If you don't ace this class, you ain't gonna get nowhere you want to be. .. Mr. Forrest will push you, and make you understand, you know, like these are things you gotta do, then they'll work. They'll keep on pushing you and pushing you until you want to go the right way.

Like Mr. Forrest. Now there's a good teacher. You know, he'll look out for every student. Try to make sure you're doing the right thing. Keep you in line and all that kind of good stuff. Make sure you don't drop out.

Ana, a special education junior, adds:

Ms. Guerrero .... She's a good teacher. She helps you any way she can.... She tries to push you, but not towards where you're gonna think, "She's annoying me" or "bothering me," She's not like that. She's like, if you want the help, you'll take it. If not, then just turn away the other way, don't take it . . . but she's like holding it for you. . .

Well, you have to change personally first, you know, then to change everything later. ... You'll start getting on the right track; you'll want to do more things, and then they'll want to help you more. More and more.

Stephanie talks about inappropriate student behavior in the classroom:

They argue with the teacher, they say bad words in front of them.... For some reason this kid popped up and said, "Mr. Smith, I need your blanking help." And he sent him out of class. Mr. Smith is a real nice guy and I don't think anybody should treat him like that. You gotta respect elders. That's what I usually do.

She adds that when she disagrees with a teacher, she does so politely and usually is able to resolve the problem amicably. Chaquan also tells about a teacher whose students make her cry but "she don't ever do nothing about it. . . she lets them run over her. They say something to her, she just let it pass. She in bed crying about them."

Tom explains that the teachers in his school are "not that bad," but:
They have to act like some way that they're really taking care of their business. ... Most teachers, kids don't respect them cuz they're not scared of the teacher. Some teachers are respectful (sic). You can just see it, when you go to that class. All of the ... I mean, even if they're bad, they won't disrespect that teacher, if they know how.... It depends on the teacher.

Rebecca agrees that the teacher has to try to keep the students under control so they can "learn the best they can." Alissa, an honors program senior, adds:

I think it's their responsibility, if they're [the students] disrupting the class, to let them know, "You're disrupting my class, I don't appreciate it. Sometimes you [the teacher] just have to tell a student, "You need to sit down and be quiet; if you have a problem with it, we'll discuss it after class. Or if you really don't like it, you can leave and go to the office."

. [There's a] separation from being in a training camp or like a strict academy or something. I think it's important to get to voice your opinion, and just share with other people, help you get to know them. Not really to be, not necessarily to be social, but, it's just important to ... I think it might teach a little bit of consideration, to say, "Wait a minute, this is what they're thinking. So, maybe I can do something to change, to make them feel more comfortable."

Lack of communication occurs when the teacher refuses to listen to the student. Chaquan tried to clarify a situation with a substitute but "she just said, 'Just gimme your number!' and I was like, 'What number you have so I could tell you if that's the right one or not?' And she wrote me up a referral." Casper's friends tried to explain what happened, getting the whole group into trouble:

\begin{abstract}
... then that one other kid, he even said, "He didn't flip off the lights." And then those two kids that didn't get in trouble, cuz they sat down, ... and then both of them said, "He didn't flip off the lights." But she didn't want to believe me. Cuz they all sticking up for me, she says. So everybody else got Saturday School and they're all trying to say, "Yeah, he wasn't even in the classroom at the time.". . . And she blamed me and I couldn't argue with her. And my whole class, even the two girls who weren't even my friends, they said I didn't do it. But she didn't want to agree.
\end{abstract}

Tracy reminds adults, "Don't always jump to believe the teacher, listen to the student, too, cuz they're people too."

The students' responses to my questions were interesting and, I think, informative. Even more significant were their spontaneous references to community. The students had a clear vision of the school's role in society, the micro society of the school itself, and the function of a discipline program in that society.

Since Plato's Republic, social philosophers have examined the role of schools in training future citizens. Antashia ex- 
plains, "You're supposed to come here and get an education. If you're tardy and you're ditching, you're not getting it. .."

Thompson and Dodder (1986) imply that, besides education, the school's function is to contain students so they stay out of trouble. Carla agrees:

\begin{abstract}
When they suspend you, you get in more trouble, cuz you're out in the street. .. And that's what happened to me once. ... I got into trouble one day cuz there was a party and they arrested everybody in that party; cuz there was a d.p., a ditching party, and that day I got in trouble more than I get in trouble at school, because I got arrested and everything.
\end{abstract}

Angela wonders how, then, students can be kept in school except to socialize:

\begin{abstract}
I know everybody, even if you're smart, even if you know that you need to be in school, you still don't like school. The only part you like about school is socializing with your friends and stuff. That's about it. All the work you have to do and everything. Unless the class is fun or something like that; maybe a few wouldn't mind going to class. Because I notice that people do that. The classes that they like, they go to, but the ones they don't like, they ditch. [It should be] a little more interesting. Cuz some teachers just give you book work. They just give you the work, they say, "Here, this is what you've gotta do; do it." And .. that's boring.
\end{abstract}

The school itself is seen as a society. Although they agreed that the purpose of the institution is education, the students' comments usually revolved around opportunities to socialize, the dearth of extracurricular activities, and the unsafe environment. Alissa described the school in terms of an extended metaphor:

This school ... it's like a little city. Some areas have the gangsters, the upper-class people, the brainy people, the people in between. ... It's just like its own little separate world. You came in, you're in one place, you go home, you're in another place.

You go in the office, they're in the government.

It's a city that definitely needs help. It needs a lot of rearranging, everything: attitudes, colleagues. I know we have a lot of new policies this year, but it always needs more work.

[The community needs to] be more interactive with the government, just like how it is in the real world. I think that a lot of the time, the government has too much power, and the community doesn't have enough sayso. Or you know, when we're talking, it's just like we're talking to hear ourselves talk, there's not nobody listening. But, I mean, it could be a good city.

Antashia agrees that the lack of community feeling is a cause of disagreement and discipline problems:

Like, you know, start making the school better for us. We sit here, we come to school all day. I know, in some parts, in some part of the day, we're gonna leave school and go have fun on our own. And go get some excitement on our own. And we come to school, it's no fun, it's boring.

We'll have lunch dances. But at lunch dances, they play like three, four English songs; lunch is thirty minutes long, but when we have that, it's extended lunch. So it's probably like an hour. And the rest is Spanish songs. Which makes people mad, which starts a fight, cuz they be like, "Ew. Why they playing that?" Then the Mexicans, you know, "That's our kind of music."

Although Robert understands the school's financial limitations, he suspects that monies spent enforcing rules and punishing offenders might be better spent in enabling taggers to use their artistic talents to beautify the school, or equipping athletes so they can contribute to school spirit instead of finding sport in harassing and evading proctors.

Discipline is a form of guidance whereby students learn the rules and procedures of society. Continuing her metaphor, Alissa explains why things could be better:

Because I know there's a lot of people here with potential that they don't even know they have. But it takes the teachers and the people in the office to bring it out of them. Because if you don't know it's there, but somebody can recognize that in you, they know what activities and assignments to give you to bring it out of you, you know, to make you a better person. That should be the focus, to keep the city going, to make it a place where somebody else might hear about it and say, "You know, that's a good place to be."

In another conversation, she addresses discipline specifically:

The teacher draws the line. Because, you know, [as a teacher] I can understand where the students need to interact with each other, and feel like they're having more responsibility, but there's a certain point, you know, you're [as a student] a child. You don't know everything. You may feel like you do. You may feel like you're misunderstood or whatever, but for right now, there's someone older than you who has been through more than you have, and they're in control... .

So what are the students learning from the school discipline procedure? Alissa observes:

The guy that runs it [Saturday School], he was telling us that it's supposed to be a punishment and stuff, and he was like asking us, "Well, what are you in here for?" and some people said, "Cuz we got in trouble," and another person said, "Cuz we got caught." So it wasn't that he did something wrong, it was just that he got caught. So, I think that a lot of people's attitude is like, "Well, you know, I can do, if I can get away with it, then it's no big deal." And it's not that they feel bad about doing it, they feel bad about getting caught. If they had the chance to do it again, and they knew they wouldn't get caught, then they probably would. 
After discussing the procedure as another learning experience to prepare her for adulthood Alissa concludes:

\begin{abstract}
We can only take what's there for us; if we find a way around it and change it and make it work for us, not necessarily hurting anybody, but, making it work for us, that's part of becoming an adult.
\end{abstract}

Rebecca agrees that warnings and punishments are a necessary component of learning about life skills. She sees warnings as a form of advice that inform students about the consequences of their actions. Punishment also is necessary, although not always effective:

\begin{abstract}
Because you can't get away with everything, just like that, just so easy. Cuz if he gets away with it, without nobody telling him anything, or punishing him, he'll just keep doing it. He'll go, "Well, this is OK. So nobody's going to tell me anything, so I can just do it over again. “. . . For some people. ... It doesn't work on all people.
\end{abstract}

The students realize that schools can't do everything. A few students will never change, for many reasons. Don explains, "There's gonna be somebody in the group that's gonna start something. So you can't . . . there's bad people everywhere you look and go...."

They suspect that the focus needs to change. Nivek says students, himself included, should concentrate on "learning, and finish[ing] school."

Antashia concludes, "No, it's not really about punishment. . Punishment's not always the answer. It could be about other things."

Alissa finishes her metaphor with the comment:

\begin{abstract}
You know, we come here and meet somebody, because everything is a cycle. I don't think anything is a coincidence. Cuz I move a lot, I just ended up here. Well, something good will come out of it cuz you're there for a reason. Like a big city that will help.
\end{abstract}

All of the students said that if they were in charge, they would talk to students who break rules, then consider adjusting schedules, changing teachers, or making other adaptations in the school or student program. They agreed that some form of punishment eventually might be necessary but were adamant in their belief that detention and suspension should be used as last resorts rather than an automatic consequence of certain behaviors.

When asked how they would handle discipline if they were administrators, the first reaction of every participant was that the administrator should talk to the student. Stephanie says, "I would tell them that teachers don't like the way they're behaving, and that when the teachers tell you what to do, you follow that."

Don adds, "Actually, you gotta listen to both of the sides. If you just take the teacher's side all the time, the student may be right and the teacher would be wrong at times. ... Teachers have to understand kids too."

Alissa emphasizes:

I think each case, I mean, it might be time-consuming, but I think each case should be looked at . . . I think I'd go into details on everything. I'd look at that person's record, to see if their attendance is up, and how their citizenship is, does this person really care, or are they just doing it to be rebellious? What? .. . I just couldn't punish everybody. ... I would just have to look at each and every circumstance before I applied that rule. That I wouldn't just say, "everybody," that I would listen first.

Angela thinks administrators should be active in solving the problem. For example, she would work with fighters:

I guess they need to talk to whoever they're having problems with, they're supposed to see what's going on, because if you sent somebody to detention, that didn't solve anything, because whenever they meet again, they'll just bring it back up, they'll start it all over again. So I don't think detention is helping fighting, if people get in fights, they need to get the two people who are in the fight and sit down and talk to them to see what's going on.

Parent involvement also is an essential factor in schoolstudent interactions. Alissa explains:

I think it's important for parent involvement, whether you have to call the house, or you know, invite them to the school. . I think if something ... was going on, you have to start talking to the parents, or whoever is in charge of them, before they leave. . . . I just really think it should be as much as you can do to help the student. ... I think it should be more parent involvement. Administration and parents and students; everybody should be interacting.

Many students said that even the threat of parent involvement is an effective deterrent. When discussing ditching, Carla says:
I would just call their parents. And then you would get in trouble for that. Cuz like my friends are like, "Uh uhh, they're gonna call my parents, I'm not gonna go." And they do, and they won't ditch any more cuz their parents. ...

The students agreed that a punitive procedure might be necessary on rare occasions, after extensive counseling, schedule changes, and other school adaptations. They also agreed that a form of removal from school would be effective because of social isolation, loss of credit, and missed learning opportunities. They indicated that they believe strongly that, to be effective, the consequences have to be given consistently and fairly harshly. They also said they would include a constructive activity, such as campus clean-up or academic work, to help them learn positive behaviors and improve their sense of value to the community. 
For learning to take place, some standard of behavior must be maintained. Nivek says, "I don't feel comfortable about it when kids mess around and everything like that. I try to put my mind on one thing or another. . . Without being a bother to anyone, I want to study." He does not suggest that we punish students who are not quiet; rather, there should be a separate place for each group to learn.

Chaquan agrees, maintaining, "I wouldn't kick no kids out of school, cuz everybody needs their education."

Don recommends a strict alternative school, but "for like two weeks; they come back out of that school learning something," ready to behave in their classes.

Carla had the same idea, but wanted a strictly enforced inschool suspension with no socializing and appropriate academic assignments. She pointed out that rules must be enforced consistently.

Antashia also believes, "If you're gonna punish somebody. . . you never stick to it. That's why people take advantage of punishment, or the punishment's not harsh enough."

Stephanie and Chaquan wanted students to be involved in campus clean-up and maintenance activities.

Alissa adds:

Something positive can come out of it too. They're negative in their class, and inconveniencing the teachers and the other people around them. Take that and do something good with it. Put them to work. ... Show, help the school look nicer, do something productive. ... I think the work would get out and they'd be like, "Man, you know, two steps away from the trash can and you just want to throw it down on the ground. Go to the trash can and put it in the trash!"

\section{CONCLUSIONS: MORE QUESTIONS}

How might these students' ideas affect discipline in their school? Primarily, I think, they cried out for liberation from rote enforcement and standard procedures. They believed that good educational practices and honest communication would avert many situations and solve some problems without the need for punishment. They admitted freely that their youth and inexperience led them to make foolish mistakes, and they looked to teachers and administrators for advice and counseling.

The students agreed that they wanted to have fun-sometimes inappropriately. Although they hoped for some latitude in expressing their exuberance, they realized that if respectful counseling did not cause a change in behavior, a negative consequence might be in order. Parent contact (which they believed should be constant throughout the education experience) was judged to be the most effective way to initiate behavior change. In a few cases, a time-out, similar to Glasser's (1990) model, or a brief alternative placement might be necessary.
The interactive research process seems to have immediate positive results. The students complained consistently about lack of communication with adults. Our conversations were structured carefully so their thoughts were valued. How did the opportunity to interact on an adult level affect these students? They demonstrated development of reflective skills as they considered their own situation in conjunction with their expressed philosophies. Reading transcripts of our conversations gave poor readers practice and encouraged the more academic students to examine their own styles of self-expression. All of the students expressed pride in their ideas and enjoyment of the interactive process.

Finding the time to discuss issues with students is difficult, but it is valuable not only for the student but also for the teacher. Jackman (1995) noted that an extended conversation with a student gave her many valuable insights. I asked secondary teachers from other districts to read the transcription to validate my understandings. They commented upon the value to them as reminders of the difference in teachers' and students' perceptions and vowed to make time to initiate conversations with their students whenever possible.

These were 14 students from a population of several thousand, in one school among thousands, at one point in time. Although their concerns may echo throughout the secondary school system, their specific priorities and suggestions probably are unique. To truly understand student reactions to discipline, one must ask the students involved, not generalize from one's own experience or the experiences of others.

\section{REFERENCES}

Barclay, W. (1959). Train up a child. Philadelphia: Westminster Press. Barritt, L., T. Beekman, H. Bleeker \& K. Mulderij. (1985). Researching educational practice. University of North Dakota: Center for Teaching and Learning.

Block, J. (1987, April). Longitudinal antecedents of ego-control and ego-resiliency in late adolescence. Paper presented at $\mathrm{Bi}$ ennial Meeting of Society for Research in Child Development, Baltimore.

Bogden, R. C., \& Biklen, S. K. (1992). Qualitative research for education: An introduction to theory and methods. Boston: Allyn and Bacon.

Brown, W. E., \& Payne, T. (1988). Policies/practices in public school discipline. Academic Therapy, 23(3), 297-301.

Brubaker, J. S. (1947). A history of the problems of education. New York: McGraw-Hill.

Butts, R. F. (1947) A cultural history of education. New York: McGraw-Hill.

Dinkins, H. K. (1981). Disciplinary problems and corrective measures in South Carolina secondary schools (doctoral dissertation, University of South Carolina, 1981). Dissertation Abstracts International, 42, AAC8129452.

Duncan, M. P. A. (1991). Perceptions of South Carolina public secondary school administrators toward major student discipline 
problems (doctoral dissertation, University of South Carolina, 1991). Dissertation Abstracts International, 52, AAC9200797.

Feldhusen, J. F. (1978). Behavior problems in secondary schools. Journal of Research \& Development in Education, 11(4), 17-28.

Gay, J. E., \& Williams, R. B. (1993). Case study training for seeing school through adolescent's eyes. Adolescence, 28(109), 13-19.

Glasser, W. (1990). The quality school: Managing students without coercion. New York: Harper Perennial.

Gretzinger, B. Q. (1988) System-wide implementation of an assertive discipline-based behavior management plan: A program evaluation (doctoral dissertation, University of Southern Mississippi, 1988). Dissertation Abstracts International, 49, AAC8902491.

Jackman, J. (1995). In knowing our students ourselves. Journal of Learning Disabilities, 28(9), 569-574.

Kampol, B. (1994). Critical pedagogy: An introduction. Westport, CT: Bergin \& Garvey.

Kratzert, W. R., \& Kratzert, M. Y. (1991). Characteristics of continuation high school students. Adolescence, 26(101), 13-17.

Kreisberg, S. (1990) Transforming power: Domination, empowerment, and education. Albany: State University of New York Press.
Kreutter, K. J. (1983). Student and teacher attitudes toward disciplinary practices in a junior high setting. (Doctoral dissertation, Temple University, 1983). Dissertation Abstracts International.

Larson, K. A., \& Karpas, M. R. (1967). Effective secondary school discipline. Englewood Cliffs, NJ: Prentice Hall.

Millman, H. L., Schaefer, C. E. \& Cohen, J. J. (1980). Therapies for school behavior problems. San Francisco: Jossey-Bass.

Shor, I. (1992). Empowering education: Critical teaching for social change. Chicago: University of Chicago Press.

Spradley, J. P. (1979). The ethnographic interview. Ft. Worth: Harcourt Brace Jovanovich College Publishers.

Thompson, W. E., \& Dodder, R. A. (1989). Containment theory and juvenile delinquency: A reevaluation through factor analysis. Adolescence, 21(82), 365-376.

Weber, T. R. (1984) Perceptions of superintendents, principals, assistant principals, deans, counselors, and teachers concerning discipline in selected Illinois high schools (doctoral dissertation, Northern Illinois University, 1984). Dissertation Abstracts International, 45, AAC8503860.

Willis, P. (1981). Learning to labor: How working class kids get working class jobs (2d ed.). New York: Columbia University Press.

\section{PERMISSIONS AND COPYRIGHT}

All rights are reserved. No part of this publication may be reproduced, photocopied, faxed, stored in a retrieval system, or transmitted, in any form or by any means, electronic, mechanical, recording or otherwise, without the prior written permission of the publisher.
Back issues are available for sale. Reproduction requires permission and payment of fees. It is illegal and a violation of federal copyright law to reproduce this publication without permission. Direct all inquiries to the permissions editor. 